\title{
PENYIDIKAN EPIDEMIOLOGI KEJADIAN LUAR BIASA DEMAM BERDARAH DENGUE
}

\author{
I Gede Purnawinadi ${ }^{1}$, Krisbi Jeri Gabriel², Suryadi Muhammad Ali ${ }^{3}$
}

\author{
${ }^{1}$ Fakultas Ilmu Keperawatan Universitas Klabat, Airmadidi-Minahasa Utara \\ ${ }^{2}$ Puskesmas Adean, Dinas Kesehatan Kabupaten Banggai Laut-Sulawesi Tengah \\ ${ }^{3}$ Fakultas Ilmu Kesehatan Masyarakat Universitas Muhammadiyah-Maluku Utara \\ Email: purnawinadi87@unklab.ac.id
}

\begin{abstract}
Abstrak
Demam berdarah dengue masih merupakan masalah kesehatan masyarakat dan salah satu penyakit menular yang potensial menimbulkan KLB. Jumlah kasus cenderung meningkat dan daerah penyebarannya bertambah luas, sehingga kejadian luar biasa masih sering terjadi di berbagai daerah di Indonesia. Tujuan penelitian ini adalah untuk memperoleh kepastian terjadinya KLB, mengetahui gambaran dan besarnya masalah KLB demam berdarah dengue yang terjadi diwilayah kerja Puskesmas Tateli. Desain penelitian yang digunakan adalah survei dan observasional analitik dengan pendekatan eksploratif deskriptif. Pelacakan kasus dilakukan dengan mempelajari rekam medik rawat inap dan register rawat jalan dari puskesmas Tateli dan data dikumpulkan secara Active Case Finding. Proses pengumpulan data menggunakan kuesioner dan lembar observasi. Analisis data epidemiologi deskriptif distribusi frekuensi berdasarkan variabel waktu, orang, tempat, serta sumber penularan. Hasil penelitian menunjukkan telah terjadi KLB DBD dari 37 kasus tersebar di 4 desa di Kecamatan Mandolang Wilayah kerja Puskesmas Tateli. Penularan terjadi pada minggu ke-37 tanggal 3 Oktober 2014 hingga minggu ke ke-7 (24 Februari 2015), faktor utama dari kebiasaan hidup dan lingkungan. Kasus tertinggi pada kelompok umur 5-14 tahun dengan jumlah 25 kasus. Attack Rate tertinggi pada kelompok umur 5-14 tahun (0,59\%) dengan CFR sebesar 2,70 pada kelompok umur 0-4 tahun. Rekomendasi untuk pihak- pihak terkait baik masyarakat untuk sadar berperilaku hidup bersih dan sehat, puskesmas, dinas kesehatan, dan institusi kesehatan lainnya untuk melakukan berbagai upaya dalam menekan kasus deman berdarah dengue.
\end{abstract}

Kata Kunci: demam berdarah dengue, kejadian luar biasa, penyidikan epidemiologi

\begin{abstract}
Dengue hemorrhagic fever is still a public health problem and one of the infectious diseases that has the potential to cause an outbreak. The number of cases tends to increase and the area of spread is wider, so that extraordinary incidents are still frequent in various regions in Indonesia. The purpose of this study was to obtain certainty about the occurrence of outbreaks, to know the description and magnitude of the dengue hemorrhagic fever outbreaks that occurred in the working area of Puskesmas Tateli. The research design used was a survey and observational analytic with a descriptive exploratory approach. Case tracking was carried out by studying inpatient medical records and outpatient registers from Puskesmas Tateli and data were collected using Active Case Finding. The data collection process uses a questionnaire and observation sheet. Descriptive epidemiological data analysis of frequency distribution based on variables of time, person, place, and source of transmission. The results showed that there had been an outbreak of dengue fever from 37 cases spread across 4 villages in Mandolang District, the working area of Puskesmas Tateli. Transmission occurred in the 37th week of October 3, 2014 until the 7th week (24 February 2015), the main factor of life habits and the environment. The highest cases were in the age group 5-14 years with 25 cases. The highest attack rate is in the 5-14 years age group (0.59\%) with a CFR of 2.70 in the 0-4 years age group. Recommendations for related parties, including the community to be aware of having a clean and healthy lifestyle, health centers, health offices, and other health institutions to make various efforts to reduce cases of dengue hemorrhagic fever.
\end{abstract}

Keywords: dengue hemorrhagic fever, outbreaks, epidemiological investigations 


\section{PENDAHULUAN}

Demam berdarah dengue (DBD) merupakan penyakit yang disebabkan oleh virus dengue yang ditularkan dari orang ke orang melalui gigitan nyamuk Aedes (Ae). Ae aegypti merupakan vektor yang paling utama, namun spesies lain seperti Ae.albopictus juga dapat menjadi vektor penular. Penyakit ini adalah penyakit demam akut yang disebabkan oleh 4 serotipe virus dengue, dan ditandai dengan empat gejala klinis utama yaitu demam yang tinggi, manifestasi perdarahan, hepatomegali, dan tanda-tanda kegagalan sirkulasi sampai timbulnya renjatan (sindroma renjatan dengue) sebagai akibat dafri kebocoran plasma yang dapat menyebabkan kematian (Depkes RI, 2010).

World Health Organization (WHO) menyatakan bahwa demam berdarah dengue merupakan penyakit tropis yang paling cepat menyebar dan dikatakan sebagai ancaman pandemi baru. Pada tahun 1950-an penyakit yang ditularkan lewat gigitan nyamuk betina ini hanya dapat ditemukan di segelintir wilayah. Kondisinya kini berbeda karena demam berdarah telah menyebar hingga ke 125 negara. Di seluruh dunia, 2 juta kasus demam berdarah dilaporkan terjadi setiap tahunnya di 100 negara, terutama di benua Asia, Afrika dan Amerika Latin serta menyebabkan 5.000-6.000 kasus kematian (Detik Health, 2013).

Berdasarkan informasi dari Pusat data dan Surveilans epidemiologi Kemenkes RI (2010), DBD masih merupakan masalah kesehatan masyarakat dan salah satu penyakit menular yang potensial menimbulkan kejadian luar biasa. Sejak pertama ditemukan penyakit DBD di Indonesia pada tahun 1968, jumlah kasus cenderung meningkat dan daerah penyebarannya bertambah luas, sehingga kejadian luar biasa (KLB)/wabah masih sering terjadi di berbagai daerah di Indonesia. Hingga kini, belum ada vaksin atau obat antivirus bagi penyakit ini. Menurut Widoyono (2008), tindakan paling efektif untuk menekan epidemi demam berdarah adalah dengan mengontrol keberadaan dan sedapat mungkin menghindari vektor nyamuk pembawa virus dengue.

Berdasarkan informasi yang diterima dari Dinas Kesehatan Provinsi Sulawesi Utara pada tanggal 27 Februari 2015 bahwa ada beberapa penderita yang berkunjung ke puskesmas dengan gejala DBD di Desa Tateli, Kecamatan Mandolang, Kabupaten Minahasa. Selanjutnya berdasarkan laporan dari Dinas Kesehatan Kabupaten Minahasa bahwa terdapat beberapa kasus DBD di Desa Tateli, Kecamatan Mandolang, Kabupaten Minahasa. Berdasarkan laporan tersebut, maka peneliti tertarik mengadakan penyidikan epidemiologi di lapangan pada tanggal 2 Maret 2015.

Kegiatan penyidikan epidemiologi ini bertujuan untuk memperoleh kepastian terjadinya KLB, mengetahui gambaran dan besarnya masalah KLB penyakit DBD yang terjadi diwilayah kerja Puskesmas Tateli. Selain itu juga untuk mengidentifikasi sumber dan cara penularan DBD, serta merumuskan saran penanggulangan dan pengendalian guna mencegah kejadian serupa dimasa yang akan datang.

\section{METODE}

Desain penelitian yang digunakan adalah survei dan observasional analitik dengan pendekatan eksploratif deskriptif. Penyidikan dilakukan di Desa Tateli Kecamatan Mandolang wilayah kerja Puskesmas Tateli Kabupaten Minahasa. Pelacakan kasus dilakukan dengan mempelajari rekam medik rawat inap dan register rawat jalan dari puskesmas Tateli 
dan petugas kesehatan yaitu bidan dan mantri Desa Tateli. Selanjutnya dilakukan pelacakan kembali penderita yang terdapat pada daftar kasus yang dilaporkan Puskesmas Tateli ke Dinas Kesehatan Kabupaten. Disamping mengidentifikasi juga dilakukan kunjungan ke rumah-rumah seluruh penderita dan mencari kasus tambahan yang tidak terlaporkan. Pengambilan data juga dengan mengobservasi lingkungan sekitar tempat tinggal penderita.

Kriteria diagnosis yang dilakukan secara klinis, epidemiologis, dan laboratoris:

1. Kriteria Klinis: demam tinggi mendadak > 39,5oC tanpa sebab yang jelas, berlangsung terus menerus selama 2-7 hari, petekie, ekimosis, purpura, perdarahan mukosa, epistaksis, perdarahan gusi, hematemesis dan atau melena.

2. Kriteria Epidemiologis: bertempat tinggal atau pernah berkunjung ke wilayah yang sedang terjangkit DBD dengan sekurangnya 1 kasus positif dalam kurun waktu 15 hari sebelum timbulnya gejala.

3. Kriteria Laboratoris: sekurangkurangnya salah satu diantara hasil pemeriksaan serologis pada Tersangka DBD, menunjukkan hasil positif pada pemeriksaan HI test atau terjadi peninggian (positif) $\mathrm{IgG}$ saja atau IgM dan IgG pada pemeriksaan dengue rapid test, Trombositopenia (100 000/ $\mu 1$ atau kurang).

Pengumpulan data sekunder untuk melengkapi informasi yang ada hubungannya dengan penyidikan KLB DBD di Desa Tateli Kecamatan Mandolang Kabupaten Minahasa adalah sebagai berikut :

1. Data geografis dan demografis dikumpulkan di kantor Kecamatan Mandolang.

2. Data dilakukan dari rekam medic rawat inap dan register rawat jalan dari
Puskesmas Tateli, dan dari bidan dan mantri di Desa Tateli.

3. Pengambilan data juga dilakukan dengan mengobservasi lingkungan sekitar tempat tinggal penderita DBD dan kegiatan pemantauan jentik.

Pengumpulan data primer dilakukan dengan cara :

1. Pelacakan penderita, data diperoleh dengan melakukan wawancara dengan penderita yang sedang sakit maupun yang sudah sembuh secara struktural dengan menggunakan kuesioner dan wawancara dilakukan pada penderita, keluarga, dan kerabat penderita berupa kontrol.

2. Pencarian kasus tambahan, data diperoleh dengan menanyakan kepada penderita, serta kepada bidan/mantri dan masyarakat Desa Tateli setempat, apakah masih ada penderita laindirumah atau di lingkungan penderita di rumah lainnya (tetangga) yang baru terjangkit.

Kasus adalah semua penderita yang dirawat dan didiagnosa oleh Dokter Puskesmas dan Rumah Sakit, sebagai penderita DBD yang ditemukan pada minggu epidemiologi ke-37 tahun 2014 yaitu bulan Oktober sampai minggu epidemiologi ke-7 2015 pada bulan Februari. Kriteria diagnosis berdasarkan kriteria WHO 1997 (Minimal 2 gejala klinis dan 2 gejala laboratoris) atau supect bila tanpa disertai pemeriksaan laboratorium. Pengambilan sampel darah tersangka DBD oleh petugas laboratorium baik yang dipuskesmas maupun di Rumah sakit melalui Vena Median Cubital.

Secara operasional kasus Demam Berdarah Dengue (DBD) adalah semua penduduk Kecamatan Mandolang Kabupaten Minahasa yang sedang sakit 
dengan gejala utama demam, sakit kepala, mual/muntah, bercak kemerahan di permukaan kulit (petikie) dan mereka yang telah sembuh dan memiliki riwayat menderita penyakit dengan gejala klinis seperti yang disebut diatas. Penderita yang didiagnosis DBD oleh Puskesmas dan Rumah sakit berdasarkan kriteria WHO tahun 1997 dan bertempat tinggal di beberapa desa di Kecamatan Mandolang Kabupaten Minahasa.

Data dikumpulkan dan diolah menggunakan program Microsoft Office Excel dan SPSS, disajikan dalam bentuk tabel, garifik, dan narasi. Data epidemiologi deskriptif yaitu menyajikan distribusi frekuensi berdasarkan distribusi tanda dan gejala penyakit serta menggambarkan KLB menurut variable waktu (memastikan KLB, periode KLB, memastikan sumber dan cara penularan), orang (kararakteristik individu yang rentan), dan tempat (luas wilayah penyebaran penyakit). Penyajian data tersebut dilakukan secara eksploratif deskriptif untuk mengetahui pola epidemiologi KLB DBD di Kecamatan Mandolang dengan data yang dikumpulkan secara Active Case Finding. Kemudian dianalisa berdasarkan statistik epidemiologi (Attack Rate dan Case Fatality Rate).

\section{HASIL DAN PEMBAHASAN}

Adanya KLB DBD sering rancu dengan adanya KLB Chikungunya, oleh karena itu berdasarkan hasil wawancara terhadap penderita dan observasi hasil laboratorium pasien dari RS, yaitu diagnosa didukung dengan pemeriksaan serologis berupa pemeriksaan IgM dan IgG Antidengue. Hal ini penting untuk penetalaksanaan manajemen terapi disamping data epidemiologis. Hasil penyelidikan KLB ditemukan gejala seperti dalam tabel 1 .
Tabel 1. Distribusi Gejala Yang Dialami Penderita Demam Berdarah Dengue (DBD)

\begin{tabular}{clll}
\hline No & \multicolumn{1}{c}{ Gejala/Tanda } & Jumlah & $\mathbf{( \% )}$ \\
\hline 1 & $\begin{array}{l}\text { Demam Tinggi } \\
\left(>39,5^{\circ} \mathrm{C}\right)\end{array}$ & 27 & 73,00 \\
2 & Sakit Kepala & 26 & 59,50 \\
3 & Nyeri Otot san Sendi & 15 & 40,50 \\
4 & Mual/Muntah & 22 & 59,50 \\
5 & Bintik-Bintik Merah & 27 & 73,00 \\
6 & Epistaksis/Mimisan & 5 & 13,50 \\
7 & Gusi berdarah & 17 & 45,90 \\
8 & Berak Darah & 0 & 0 \\
9 & Kesadaran Menurun & 6 & 16,20 \\
\hline
\end{tabular}

Bulan Oktober 2014 - Februari 2015

Berdasarkan tabel 1. persentase gejala klinis tertinggi adalah demam dan bintik merah sebesar $(73,0 \%)$, diikuti sakit kepala sebanyak 26 orang (73\%), mual/muntah sebanyak 22 orang (59,5 $\%)$, gusi berdarah 17 orang $(45,9 \%)$, nyeri otot dan sendi 15 orang $(40,5$ $\%$ ),dan gejala klinis terendah adalah kesadaran menurun 6 orang $(16,2 \%)$ dan epitaksis/mimisan 5 orang $(13,5 \%)$, sedangkan untuk gejala klinis berak darah tidak ada satupun pasien yang mengalami.

Sumber data untuk menetapkan adanya KLB DBD adalah laporan mingguan penyakit potensi wabah (W2) dan telah di crosss-check dengan laporan angka kesakitan bulanan dan dibandingkan dengan laporan data selama 5 tahun. Dari gambar 1. Kurva maksimum minimum DBD, dapat dilihat dari bulan Januari sampai Desember, jumlah kasus tertinggi berada pada bulan Januari dan Mei yaitu 6 kasus, di bulan Desember hanya terdapat 5 kasus saja. Sehingga tidak ada peningkatan jumlah kasus yang signifikan, namun setelah masuk pada tahun 2015 bulan Januari jumlah kasus meningkat 3 kali lipat menjadi 17 kasus, maka dari itu berdasarkan peningkatan tersebut dapat ditetapkan menjadi KLB DBD. 


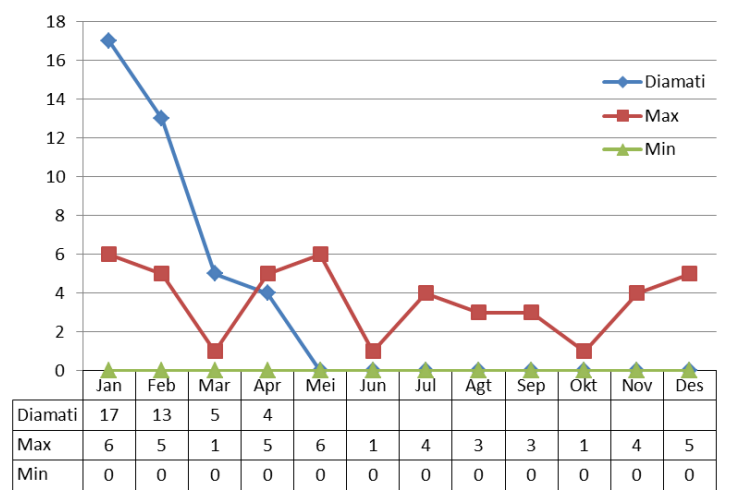

Gambar 1. Kurva Pola Maksimum Minimum Kasus DBD Tahun 2010 - 2014 Dibandingkan Dengan Tahun 2015

Disamping itu, berdasarkan dari dan hasil penyidikan lapangan epidemiologi, pada bulan Oktober 2014 terdapat 1 kasus yang meninggal dunia yang disebabkan oleh penyakit DBD. Sesuai dengan Kriteria Penetapan KLB oleh Depkes RI (2015) yang menyatakan bahwa ketika terjadi peningkatan jumlah kematian yang berarti, maka dapat dikatakan telah terjadi KLB pada bulan Oktober 2014 di wilayah kerja Puskesmas Tateli Kecamatan Mandolang Kabupaten Minahasa.

Hasil penyidikan di Kecamatan Mandolang Kabupaten Minahasa dimulai pada minggu epidemiologi ke-37 tanggal 3 Oktober 2014 pada seorang anak usi 3 tahun, kemudian kasus berlanjut sampai penyidikan epidemiologi dilaksakan pada tanggal 2 Maret 2015. Jumlah kasus keseluruhan yang ditemukan di lokasi KLB adalah sebanyak 37 penderita dan tidak ada yang meninggal. Untuk lebih jelasnya dapat dilihat pada kurva epidemiologi.

Dari grafik kurva epidemik memperlihatkan bahwa mulai terjadi penularan pada minggu ke-37 (3 Oktober 2014) dan lanjut hingga minggu ke-7 (24 Februari 2015). Berdasarkan kurva epidemiologi ada beberapa puncak dan puncak tertinggi berada pada minggu ke46 (15 Desember 2014) dan menggu ke-
6 (10 Februari 2015). Kirva epidemic kasus DBD menunjukkan penularan dari orang ke orang yang disebut dengan Propagated. Walaupun gambaran kurva seperti telah mencapai puncak dan telah direspon dengan pengobatan, namun pemantauan wilayah tempat KLB harus tetap dilakukan sebagai upaya untuk memutuskan rantai penularan dan mencegah meluasnya kejadian kasus.

\section{Gambar 2. Kurva Epidemiologi DBD Bulan Desember 2014 - Februari 2015}

Hasil penyidikan epidemiologi diperoleh data bahwa dari 37 kasus tersebar di 4 (empat) Desa di Kecamatan Mandolang Wilayah kerja Puskesmas Tateli Kecamatan Mantan Mandolang Kabupaten Minahasa, seperti pada table berikut:

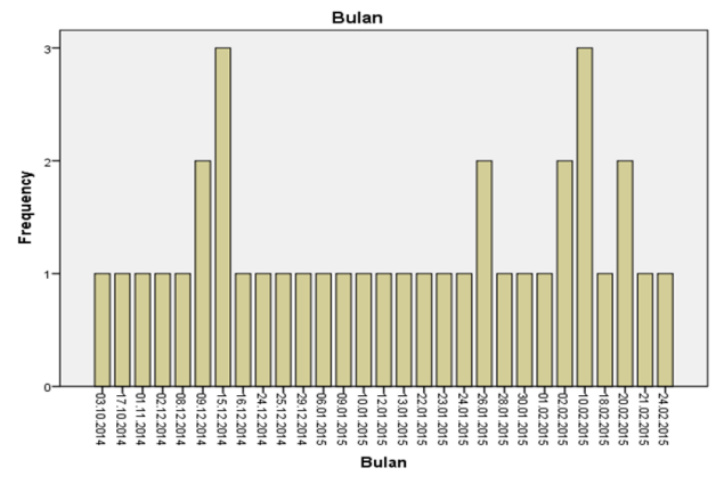

Table 2. Distribusi Penderita DBD Menurut Desa Bulan Oktober 2014 - Februari 2015

\begin{tabular}{lcc}
\hline Nama Desa & Jumlah & Persentase $(\%)$ \\
\hline Desa Tateli & 21 & 56,8 \\
Desa Kalasey & 7 & 18,9 \\
Desa Koha & 8 & 21,6 \\
Desa Agotey & 1 & 2,7 \\
Jumlah & 37 & 100 \\
\hline
\end{tabular}

Tabel 2. menunjukkan bahwa kasus DBD tertinggi berada di Desa Tateli dengan jumlah 21 kasus $(56,8 \%)$ dan terendah di Desa Agotey dengan jumlah 1 kasus $(2,7 \%)$. Berdasarkan hasil wawancara Index Case berada di Desa Tateli, dimana rumah tersebut merupakan tempat penyabungan ayam. Hasil penyidikan bahwa rumah tersebut 
merupakan satu-satunya tempat penyabungan ayam yang berada di Desa Tateli, pengunjung yang datang di tempat ini sangat banyak, baik ikut dalam kegiatan penyabungan maupun yang hanya menonton, asal pengunjung yang datang berasal dari berbagai desa/daerah. Hasil pemantauan di rumah ini, ditemukan adanya ban bekas yang dibelah menjadi dua bagian yang merupakan breeding place sebagai tempat perkembangan jentik nyamuk, dimana nyamuk tersebut yang mungkin belum membawa parasit kemudian menggigit para pengunjung yang mungkin telah terinfeksi dari daerah yang sedang mewabah dan daerah endemis DBD, sehingga nyamuk tersebut menjadi pembawa parasit aktif DBD (Dianti, Budiyono, Joko, 2019).

Kasus DBD yang ditemukan di Kecamatan Mandolang Mulai dari penderita usia balita sampai orang dewasa. Deskripsi golongan umur seperti tabel berikut:

Tabel 3. Distribusi Penderita DBD Menurut Golongan Umur dan Jenis Kelamin

\begin{tabular}{|c|c|c|c|c|c|c|c|}
\hline \multirow[t]{2}{*}{$\begin{array}{l}\mathrm{N} \\
\mathrm{o}\end{array}$} & \multirow[t]{2}{*}{$\begin{array}{l}\text { Golonga } \\
\text { n Umur } \\
\text { (Tahun) }\end{array}$} & \multicolumn{2}{|c|}{$\begin{array}{l}\text { Jumlah } \\
\text { Penderita }\end{array}$} & \multirow[t]{2}{*}{$\begin{array}{l}\text { Tota } \\
1\end{array}$} & \multicolumn{2}{|c|}{$\begin{array}{l}\text { Jumlah } \\
\text { Kematia } \\
\mathrm{n}\end{array}$} & \multirow[t]{2}{*}{$\begin{array}{l}\text { Tota } \\
1\end{array}$} \\
\hline & & $\mathrm{L}$ & $\mathrm{P}$ & & $\mathrm{L}$ & $\mathrm{P}$ & \\
\hline 1 & $0-4$ & 5 & 0 & 5 & 1 & 0 & 1 \\
\hline 2 & $5-14$ & $\begin{array}{l}1 \\
4\end{array}$ & $\begin{array}{l}1 \\
1\end{array}$ & 25 & 0 & 0 & 0 \\
\hline 3 & $\begin{array}{l}15- \\
44\end{array}$ & 5 & 2 & 7 & 0 & 0 & 0 \\
\hline 4 & $>45$ & 0 & 0 & 0 & 0 & 0 & 0 \\
\hline Total & & $\begin{array}{l}2 \\
4\end{array}$ & $\begin{array}{l}1 \\
3\end{array}$ & 37 & 1 & 0 & 1 \\
\hline
\end{tabular}

Tabel 3 menunjukkan bahwa kasus tertinggi pada kelompok umur 5 14 tahun dengan jumlah 25 kasus, diikuti kelompok umur 15 - 44 tahun dengan jumlah 7 kasus, dan kasus terendah berada pada kelompok umur 0 - 4 tahun dengan jumlah 5 kasus. Dengan jumlah kematian kematian 1 orang pada golongan umur $0-4$ tahun.
Berdasarkan tabel 4. dapat kita lihat bahwa Attack Rate tertinggi pada kelompok umur 5-14 tahun dengan jumlah $0,59 \%$ dan terendeh pada kelompok umur 15-44 tahun dengan jumlah 0,08\% dengan CFR sebesar 2,70 pada kelompok umur 0-4 tahun.

Table 4. Distribusi Attack Rate dan Case Fatality Rate

\begin{tabular}{|c|c|c|c|c|}
\hline \multirow{2}{*}{$\begin{array}{l}\text { Gol.Umur } \\
\text { (Tahun) }\end{array}$} & \multirow{2}{*}{$\begin{array}{l}\text { Jumlah } \\
\text { Penduduk }\end{array}$} & \multicolumn{2}{|c|}{ Total } & \multirow[b]{2}{*}{ CFR } \\
\hline & & Kasus & $\mathrm{AR}$ & \\
\hline $0-4$ & 2.341 & 5 & 0,21 & 2,70 \\
\hline $5-14$ & 4.278 & 25 & 0,59 & 0 \\
\hline $15-44$ & 8.437 & 7 & 0,08 & 0 \\
\hline$>45$ & 3.842 & 0 & 0 & 0 \\
\hline Jumlah & 19.875 & 37 & 0,88 & 2,70 \\
\hline
\end{tabular}

Berdasarkan hasil wawancara terstruktur terhadap penderita dan keluarga menggunakan kuesionar, diketahui bahwa Index case dari kasus KLB DBD ini adalah seorang anak usia 3 tahun, yang bertempat tinggal di Desa Tateli. Lokasi kasus pertama ini merupakan tempat persabungan ayam, dan dari penyidikan didapatkan bahwa ditempat tersebut banyak terdapatkan ban bekas yang merupakan breeding place dari jentik nyamuk sebagai sumber penularan.

Tabel 5. Perbedaan Proporsi antara Hasil Wawancara dan Hasil Pengamatan Faktor Kebiasaan Hidup dan Lingkungan

\begin{tabular}{|c|c|c|c|c|c|c|c|c|}
\hline \multirow{3}{*}{$\begin{array}{l}\text { Faktor } \\
\text { Kebiasaan } \\
\text { Hidup dan } \\
\text { Lingkungan } \\
\end{array}$} & \multicolumn{4}{|c|}{ Wawancara } & \multicolumn{4}{|c|}{ Pengamatan } \\
\hline & \multirow{2}{*}{$\frac{\mathrm{Ya}}{\mathrm{Jlh}}$} & & \multicolumn{2}{|c|}{ Tidak } & \multirow{2}{*}{$\frac{\mathrm{Ya}}{\mathrm{Jlh}}$} & & \multicolumn{2}{|c|}{ Tidak } \\
\hline & & $\%$ & $\mathrm{Jlh}$ & $\%$ & & $\%$ & Jlh & $\%$ \\
\hline $\begin{array}{l}\text { Adanya baju } \\
\text { Bergantung }\end{array}$ & 35 & $\begin{array}{c}94 . \\
6\end{array}$ & 2 & 5.4 & 36 & $\begin{array}{c}97 . \\
3\end{array}$ & 1 & 2.7 \\
\hline $\begin{array}{l}\text { Pengurasan bak } \\
\text { penampungan } \\
\text { air }\end{array}$ & 9 & $\begin{array}{c}24 . \\
3\end{array}$ & 28 & $\begin{array}{c}75 . \\
7\end{array}$ & 9 & $\begin{array}{c}24 . \\
3\end{array}$ & 28 & $\begin{array}{c}75 . \\
7\end{array}$ \\
\hline $\begin{array}{l}\text { Pemberian } \\
\text { bubuk abate }\end{array}$ & 7 & $\begin{array}{c}18 . \\
9\end{array}$ & 30 & $\begin{array}{c}81 . \\
1\end{array}$ & 7 & $\begin{array}{c}18 . \\
9\end{array}$ & 30 & $\begin{array}{c}81 . \\
1\end{array}$ \\
\hline $\begin{array}{l}\text { Timbunan } \\
\text { sampah } \\
\text { disekitar rumah }\end{array}$ & 37 & $\begin{array}{c}10 \\
0\end{array}$ & 0 & 0 & 37 & $\begin{array}{c}10 \\
0\end{array}$ & 0 & 0 \\
\hline $\begin{array}{l}\text { Timbunan } \\
\text { kaleng dan ban } \\
\text { bekas }\end{array}$ & 33 & $\begin{array}{c}89 . \\
2\end{array}$ & 4 & $\begin{array}{c}10 . \\
8\end{array}$ & 35 & $\begin{array}{c}94 . \\
6\end{array}$ & 2 & 5.4 \\
\hline \multirow[t]{2}{*}{$\begin{array}{l}\text { Adanya } \\
\text { tonggak bambu }\end{array}$} & 7 & $\begin{array}{c}18 . \\
9\end{array}$ & 30 & $\begin{array}{c}81 . \\
1\end{array}$ & 7 & $\begin{array}{c}18 . \\
9\end{array}$ & 30 & $\begin{array}{c}81 . \\
1\end{array}$ \\
\hline & 28 & $\begin{array}{c}75 . \\
7\end{array}$ & 9 & $\begin{array}{c}24 . \\
3\end{array}$ & 28 & $\begin{array}{c}75 . \\
7\end{array}$ & 9 & $\begin{array}{c}24 . \\
3\end{array}$ \\
\hline
\end{tabular}


PSN melalui

fogging

Adanya jentik dibak mand

Dari tabel 5 dapat dilihat yang menjadi faktor utama yang menjadi sumber dan cara penularan, yang ditinjau dari kebiasaan hidup dan lingkungan yang mempengaruhi penyebaran penyakit yaitu adanya timbunan sampah berdasarkan hasil wawancara dan pengamatan 37 responden (100\%), kebiasaaa menggantung baju dalam rumah dengan hasil wawancara 35 responden (94.6\%) dan pengamatan 36 (97.3\%), adanya timbunan kaleng dan ban bekas berdasarkan hasil wawancara 33 responden $(89.2 \%)$ dan pengamatan 35 (94.6\%), kebiasaan menguras bak penampungan air berdasarkan wawancara dan pengamatan 9 responden (24.3\%), penggunaan bubuk abate berdasarkan wawancara dan pengamatan 7 responden (18,9\%), sehingga menimbulkan adanya jentik di bak mandi berdasarkan wawancara 25 responden (67.6\%) dan berdasarkan pengamatan 33 responden $(89.2 \%)$, maka dilakukan tindakan Pemberantasan Sarang Nyamuk (PSN) melalui fogging, dengan hasil wawancara dan pengamatan 28 responden $(75.7 \%)$.

Penyakit DBD ditularkan oleh nyamuk Aedes Aegypti dan Aedes Albopictus seperti halnya vektor penularan Chikunggunya. Banyak tempat perindukan nyamuk sering berhubungan dengan peningkatan kejadian DBD. Oleh karena itu penanggulangan vektor penyakit DBD sama dengan upaya pengendalian vektor DBD yaitu PSN (Pemberantasan Sarang Nyamuk) baik secara fisik $(3 \mathrm{M}=$ Menutup, Menimbun dan Menguras), kimiawi (temephos), maupun biologis (Ikan pemakan jentik) (Pratiwi, 2009).

$\begin{array}{ccc}\text { Pengendalian } & \text { vektor } & \text { adalah } \\ \text { upaya menurunkan } & \text { faktor } & \text { resiko }\end{array}$

penularan oleh vektor dengan meminimalkan habitat perkembangbiakan vektor, penurunan kepadatan dan umur vektor, mengurangi kontak antara vektor dengan manusia serta memutus rantai penularan penyakit. Metode pengendalian vektor DBD bersifat spesifik lokal, dengan mempertimbangkan faktor-faktor lingkungan fisik (cuaca/iklim, permukiman dan habitat perkembangbiakan); lingkungan social budaya (pengetahuan, sikap dan perilaku) dan aspek vektor. Pada dasarnya metode pengendalian vektor DBD yang paling efektif adalah dengan melibatkan peran serta masyarakat sehingga berbagai metode pengendalian vektor dengan cara lain merupakan upaya pelengkap yang secara cepat memutus rantai penularan (Depkes RI, 2010).

\section{KESIMPULAN DAN SARAN}

Diagnosa klinis yang digunakan sebagai kasus pada KLB DBD ini dengan gejala klinis yaitu demam tinggi mendadak > 39,5oC, petekie, ekimosis, purpura, perdarahan mukosa, epistaksis, perdarahan gusi, hematemesis dan atau melena. Untuk menegakkan diagnosa secara laboratorium tidak dilakukan mengingat untuk pemeriksaan variasi PCR tidak dapat dilakukan dan sampel harus dikirim ke Jakarta untuk pemeriksaan laboratorium secara lengkap. Telah terjadi KLB DBD berdasarkan gejala klinis yang ada di tempat KLB berlangsung.

Hasil penyidikan epidemiologi diperoleh data bahwa dari 37 kasus tersebar di 4 (empat) Desa di Kecamatan Mandolang Wilayah kerja Puskesmas Tateli. Penularan terjadi pada minggu ke37 tanggal 3 Oktober 2014 hingga minggu ke ke-7 (24 Februari 2015). Kasus tertinggi pada kelompok umur 514 tahun dengan jumlah 25 kasus, diikuti kelompok umur 15-44 tahun dengan jumlah 7 kasus, dan kasus terendah 
beradah pada kelompok umur 0-4 tahun dengan jumlah 5 kasus. Attack Rate tertinggi pada kelompok umur 5-14 tahun dengan jumlah $0,59 \%$ dan terendeh pada kelompok umur 15-44 tahun dengan jumlah 0,08\% dengan CFR sebesar 2,70 pada kelompok umur 0-4 tahun.

Indeks case dari kasus KLB DBD ini adalah seorang anak usia 3 tahun, yang bertempat tinggal di Desa Tateli. Lokasi kasus pertama ini merupakan tempat persabungan ayam, dan dari penyidikan didapatkan bahwa ditempat tersebut banyak terdapatkan ban bekas yang merupakan breeding place dari jentik nyamuk.

Berdasarkan hasil penyidikan, yang menjadi faktor utama yang menjadi sumber dan cara penularan, yang ditinjau dari kebiasaan hidup dan lingkungan yang mempengaruhi penyebaran penyakit yaitu adanya timbunan sampah berdasarkan hasil wawancara dan pengamatan 37 responden $(100 \%)$, kebiasaan menggantung baju dalam rumah dengan hasil wawancara 35 responden $(94.6 \%)$ dan pengamatan 36 (97.3\%), adanya timbunan kaleng dan ban bekas berdasarkan hasil wawancara 33 responden $(89.2 \%)$ dan pengamatan 35 (94.6\%), kebiasaan menguras bak penampungan air berdasarkan wawancara dan pengamatan 9 responden (24.3\%), penggunaan bubuk abate berdasarkan wawancara dan pengamatan 7 responden (18,9\%), sehingga menimbulkan adanya jentik di bak mandi berdasarkan wawancara 25 responden (67.6\%) dan berdasarkan pengamatan 33 responden (89.2\%), maka dilakukan tindakan Pemberantasan Sarang Nyamuk (PSN) melalui fogging, dengan hasil wawancara dan pengamatan 28 responden $(75.7 \%)$..

Rekomendasi yang dapat diberikan kepada berbagai pihak adalah sebagai berikut:
1. Kepada masyarakat Kecamatan Mandolang

a. Pengendalian vektor yang paling efektif dan efisien adalah dengan pemutusan rantai penularan melalui pemberantasan jentik. Pelaksanaan dimasyarakat dilakukan melalui upaya PSN (Pemberantasan Sarang Nyamuk) Demam Berdarah Dengue dalam bentuk kegiatan 3M Plus. Untuk mendapatkan hasil yang diharapkan kegiatan 3M Plus ini harus dilakukan secara serempak dan terus menerus atau berkesinambungan.

b. Diharpkan masyarakat menutup tempat penampungan air bagi yang memiliki tempat penampungan air dan ritin mengurasnya minimal 3 kali seminggu.

c. Bila terdapat ban, kaleng, botol bekas serta tempurung kelapa dan potongan banbu dihalaman rumah supaya dikubur atau ditimbun untuk mencegam berkembangbiaknya nyamuk.

d. Tidak membiarkan menggantung pakaian di kamar.

e. Menggunakan obat antinyamuk.

2. Ditujukan Kepada Pihak Kepala Desa Dan Perangkat Desa

a. Mengkordinir kegiatan PSN.

b. Mengkordinis kader untuk pemantauan jentik nyamuk.

\section{Puskesmas}

a. Melakukan pengamatan terhadap timbulnya kasus DBD secara rutin atau pengamatan terhadap peningkatan kasus agar segera dilakukan intervensi.

b. Melakukan investigasi dilapangan dan melakukan pengobatan secara masal.

c. Memberikan penyuluhan kepada masyarakat dan pemantauan 
secara berkala oleh kader kesehatan.

d. Tanggap terhadap adanya peningkatan kunjungan pelayanan karena suatu penyakit dan melakukan penyidikan epidemiologi untuk mengetahui kebenaran di lapangan.

4. Dinas Kesehatan Kabupaten Minahasa

a. Melakukan SKD (Sistem Kewaspadaan Dini) terhadap penyakit potensial KLB termasuk penyakit DBD di wilayah Kabupaten Minahasa, dengan menggerakan Puskesmas agar supaya ada pantauan perkembangan penyakit tersebut sehingga tidak menyebar kewilayah lain.

b. Menginstruksikan Puskesmas untuk melaksanakan PJB (Pemantauan Jentik Berkala) sesuai dengan frekuensi pelaksanaan dan ketepatan pelaksanaan yang seharusnya.

\section{REFERENSI}

Bagian Data dan Statistik Kecamatan Mandolang. (2014). Data Kecamatan Mandolang Kabupaten Minahasa.

Chen K., Pohan H.T., Sinto R. (2009). Diagnosis dan Terapi Cairan pada Demam Berdarah Dengue. Medicinus 22 (1): 3-7.

Departemen Kesehatan Republik Indonesia. (2010). Pencegahan dan Pemberantasan Demam Berdarah Dengue. Jakarta: Dirjen P2L.

Dianti, I., Budiyono, B., Joko, T. (2019). Nutrition Factors in Breeding Place Media and Larva Density of Aedes Aegypti. Journal of Public
Health for Tropical and Coastal Region, vol. 2, no. 2, pp. 33-39. [Online] https://ejournal2.undip.ac.id/index. php/jphtr/article/view/6188

Djunaedi, D. (2006), Demam Berdarah. Malang: UMM Press.

Detikhealth. (2013). Demam Berdarah, Penyakit Tropis yang Paling Cepat Menular.

http://health.detik.com/read/2013/0 1/17/174526/2145487/763/ whodemam-berdarah-penyakit-tropisyang-paling-cepat-menular. Diakses 22 Mei 2015.

Gubler D.J. (1998). Dengue and Dengue Hemorrhagic Fever. Clinical Microbiology Reviews 11 (3): 480496.

Lestari, K. (2007). Epidemiologi Dan Pencegahan Demam Berdarah Dengue (DBD) di Indonesia. Farmaka, Vol. 5 No. 3, Desember 2007. Jatinangor: Fakultas Farmasi Universitas Padjadajaran.

M. N. Bustan. (1997). Pengantar Epidemiologi. Jakarta: PT Rineka Cipta.

Pratiwi D.S. (2009). Demam Berdarah Dengue, Cara Mencegah dan Menanggulanginya. Dinas Kesehatan Kota Surabaya. Available from: http://www.surabayaehealth.org/dkksurabaya/berita/de mam-berdarah-dengue-caramencegah-dan-menanggulanginya. Diakses 22 Mei 2015.

Puskesmas Tateli Kecamatan Mandolang Kabupaten Minahasa. (2014). Profil Kesehatan Puskesmas Mandolang Tahun 2014. Bagian 
Pusat dan Data Kesehatan (PUSDAKES).

Rena, Ni Made Renny a, dkk. (2009). Kelainan Hematologi pada Demam Berdarah Dengue. J Peny Dalam, Volume 10 Nomor 3 September 2009. Denpasar: FK Unud RSUP Sanglah Denpasar.

Soegijanto H.S. (2006). Patogenesa dan Perubahan Patofisiologi Infeksi Virus Dengue. Jakarta

Widoyono. (2008). Penyakit Tropis: Epidemiologi, Penularan, Pencegahan, dan Pemberantasannya. Jakarta: Erlangga.

World Health Organization. (2000). Demam Berdarah Dengue: Diagnosis, Pengobatan, Pencegahan, dan Pengendalian. Edisi 2. Jakarta: EGC.

World Health Organization. (1997). Dengue Haemorrhagic Fever, Treatment, Prevalention and Control. 2nd edition. WHO 